Abstracta Iranicacta Iranica

Revue bibliographique pour le domaine irano-aryen

Volume 34-35-36 | 2017

Comptes rendus des publications de 2011-2013

\title{
Antigoni Zournatzi. The Median Logos of Herodotus and the Persians' Legitimate Rule of Asia
}

\section{Rémy Boucharlat}

\section{(2) OpenEdition}

1 Journals

\section{Édition électronique}

URL : http://journals.openedition.org/abstractairanica/42177

DOI : 10.4000/abstractairanica.42177

ISSN : 1961-960X

Éditeur :

CNRS (UMR 7528 Mondes iraniens et indiens), Éditions de l'IFRI

Référence électronique

Rémy Boucharlat, «Antigoni Zournatzi. The Median Logos of Herodotus and the Persians' Legitimate Rule of Asia », Abstracta Iranica [En ligne], Volume 34-35-36 | 2017, document 124, mis en ligne le 30 juillet 2017, consulté le 02 octobre 2020. URL : http://journals.openedition.org/abstractairanica/42177 ;

DOI : https://doi.org/10.4000/abstractairanica.42177

Ce document a été généré automatiquement le 2 octobre 2020.

Tous droits réservés 


\title{
Antigoni Zournatzi. The Median Logos of Herodotus and the Persians' Legitimate Rule of Asia
}

\author{
Rémy Boucharlat
}

\section{RÉFÉRENCE}

Antigoni Zournatzi. «The Median Logos of Herodotus and the Persians' Legitimate Rule of Asia ». IA, 48, 2013, p. 221- 252.

1 Une nouvelle pièce à verser au dossier Hérodote dont l'épaisseur croit d'année en année sans pour autant apporter de solution aux problèmes que pose ses Histoires. L'A. discute ici de l'origine, perse ou grecque, du concept de la séquence des trois empires successifs, assyrien, mède et perse, qui recouvre l'Asie, tel qu'il est exprimé par Hérodote, dans son Medikos logos (Hist. 1. 95. - 107 et 107-30). La question a été maintes fois discutée depuis un siècle, tant l'origine que la date à laquelle le thème apparaît. Rien n'y fait allusion dans les sources écrites achéménides. L'auteur grec a eu accès à des documents ou des informations, non vérifiables, et cela pour l'époque mède également, ce qui le conduit à établir une succession du Mède Astyage à son supposé petits-fils, Cyrus. Les Mèdes - le royaume mède par nécessité, chez Hérodote constituent bien l'élément charnière dans le dispositif des empires successifs, au point que la conquête du " royaume » d'Astyage, puis du royaume de Crésus, équivaut à la mainmise de Cyrus sur « toute l'Asie » (Hist. 1.130.2-3), alors que les conquêtes de l'Asie Mineure occidentale et celle de Babylone, sans compter celles des régions de l'Iran oriental, sont postérieures. Du côté perse, la légitimité de Cyrus à la succession est illustrée par le contenu du Cylindre de Babylone, ou la représentation d'éléments élamo-mésopotamiens à Pasargades - Babylone étant l'héritière des Assyriens - et même égyptiens, même s'il n'a connu l'Égypte qu'à travers sa mainmise partielle sur le 
Levant. La réalité et l'origine de la théorie des empires successifs n'ont pas fini d'alimenter la recherche.

\section{AUTEURS}

\section{RÉMY BOUCHARLAT}

UMR 5133 CNRS-Université de Lyon 